ARTICLE

\title{
Larval fish assemblages in two nearshore areas of the Humboldt Current System during autumn-winter in northern Chile
}

Ensambles de larvas de peces en dos áreas costeras del Sistema de Corrientes de Humboldt durante otoño-invierno en el norte de Chile

\section{Lissette D. Paredes ${ }^{1,2^{*}}$, Mauricio F. Landaeta ${ }^{3,4}$ and M. Teresa González ${ }^{2}$}

\begin{abstract}
${ }^{1}$ Programa de Magíster en Ecología de Sistema Acuáticos, Facultad de Ciencias del Mar y Recursos Biológicos, Universidad de Antofagasta, Avenida Universidad de Antofagasta 02800, Antofagasta, Chile. *Corresponding author: lissette.paredes@uantof.cl ${ }^{2}$ Instituto de Ciencias Naturales AvH, Facultad de Ciencias del Mar y Recursos Biológicos, Universidad de Antofagasta, Avenida Universidad de Antofagasta 02800, Antofagasta, Chile

${ }^{3}$ Laboratorio de Ictioplancton (LABITI), Facultad de Ciencias del Mar y de Recursos Naturales, Universidad de Valparaíso, Avenida Borgoño 16344, Reñaca, Viña del Mar, Chile

${ }^{4}$ Centro de Observación Marino para Estudios de Riesgos del Ambiente Costero (COSTA-R), Universidad de Valparaíso, Chile

Resumen.- Se analizaron patrones espaciales y temporales en la composición de larvas de peces en dos áreas costeras pertenecientes al Sistema de la Corriente de Humboldt (HCS), en el norte de Chile. Cinco muestreos fueron realizados en Isla Santa María (ISM) y Punta Coloso (COL), Península de Mejillones. El ictioplancton fue recolectado cada 15 días durante la temporada otoño-invierno austral en 2014 (mayo a agosto). Un total de 412.410 larvas de peces pertenecientes a 36 taxa fueron identificadas, una alta abundancia comparada con otras regiones del HCS. Se registraron similares especies en comparación al centro de Chile, así como diferentes especies respecto del centro de Perú; se compartieron varias familias entre estas regiones del HCS y otros sistemas (por ejemplo, Sistema de Canarias). ISM fue dominado por especies del intermareal-submareal (por ejemplo, Helcogrammoides cunninghami), mientras que Engraulis ringens fue predominante en COL. Varias especies se correlacionaron positivamente con oxígeno disuelto (por ejemplo, Auchenionchus microcirrhis), así como con temperatura y transporte de Ekman (por ejemplo, Sebastes oculatus), mientras que otras se correlacionaron negativamente con los mismos parámetros ambientales (por ejemplo, Graus nigra). Los resultados sugieren que las larvas de peces podrían utilizar diferencialmente estas áreas, como refugio o zona de alimentación, y que los peces adultos estarían acoplando sus periodos de desove con procesos oceanográficos a corta escala temporal. Este estudio describe por primera vez los ensambles de larvas de peces en áreas costeras del norte de Chile, resaltando su importante rol en los primeros estados de desarrollo de los peces.
\end{abstract}

Palabras clave: Ictioplancton, peces epipelágicos, peces intermareales-submareales, Sistema de la Corriente de Humboldt

\begin{abstract}
This paper presents an analysis of spatial and temporal patterns in the fish larvae composition of two geographically adjacent nearshore areas within the Humboldt Current System (HCS), northern Chile. Five surveys were performed at Isla Santa María (ISM) and Punta Coloso (COL), Mejillones Peninsula. Ichthyoplankton were collected every 15 days in 2014 during the austral autumn-winter (May to August). A total of 412,410 fish larvae belonging to 36 taxa were identified, a high abundance compared with other HCS regions. Data also revealed similarities in species recorded compared with central Chile as well as differences compared with central Peru; a number of families were shared between these HCS regions and other systems (e.g., Canarias Current System). ISM was dominated by intertidal-subtidal species (e.g., Helcogrammoides cunninghami), while Engraulis ringens was most abundant at COL. Several species were positively correlated with dissolved oxygen (e.g., Auchenionchus microcirrhis), as well as temperature and Ekman transport (e.g., Sebastes oculatus), while the presence of others is negatively related to the same environmental parameters (e.g., Graus nigra). Results suggest that larvae differently utilize these two areas as a refuge or for feeding, and that adults might be coupling their spawning periods with short-term oceanographic features. Larval fish assemblages of nearshore areas in northern Chile are described here for the first time and highlight the important role of these two areas in the early developmental stages of fish species.
\end{abstract}

Key words: Ichthyoplankton, epipelagic fishes, intertidal-subtidal fishes, Humboldt Current System 


\section{INTRODUCTION}

The Humboldt Current System (HCS) in the southeastern Pacific Ocean is a highly productive marine ecosystem that supports one of the largest anchovy and sardine fisheries in the world (Mann \& Lazier 1991, Chavez \& Messié 2009, Ayon et al. 2011). Previous research on the HCS has therefore been focused mainly on the biology of adult fish and the management of this industry; although our knowledge about the early life stages of marine fish species has increased significantly in recent decades, many aspects of the ecology and dynamics of ichthyoplankton assemblages in nearshore areas still remain unknown.

Nearshore zones are characterized as environments that provide high food abundance, refuge against predators and suitable ecophysiological conditions for the development of all fish life history stages (Olivar et al. 2010, Pattrick \& Strydom 2014, Rabbaniha et al. 2015). A number of previous studies have highlighted the importance of shallow nearshore zones as spawning and nursery areas, as well as for the recruitment of larval fish species with offshore and inshore habitats (Strydom 2003, Borges et al. 2007, Landaeta et al. 2015).

The distribution and abundance of larval fish assemblages are modulated by hydrographic (e.g., temperature, dissolved oxygen, nutrients) (JohnsonColegrove et al. 2015) and hydrodynamic processes (e.g., upwelling shadows, frontal zones, eddies) (Castro et al. 2000, Olivar et al. 2016). These factors can influence the quantity and quality of food availability as well as reproductive pulses, behavioral adaptations, the duration of pelagic larval stages, and the survival of different developmental stages (Landaeta \& Castro 2006, Yannicelli et al. 2006, Bustos et al. 2008). Coastal geomorphological features are also important for the accumulation and retention of larval fish abundance (Paris \& Cowen 2004, Velez et al. 2005, Álvarez et al. 2015), while bathymetric features as well as distance from the coast can determinate distributions (Hernández-Miranda et al. 2003, Adkins et al. 2016). Variations in all these characteristics can result in completely different structures and diversities of fish larval assemblages (Smith \& Suthers 1999).

The nearshore area around northern Chile is known to be one of the most productive zones within the HCS. This area are largely influenced by a constant upwelling input, which maintain high level of biological productivity (Marín et al. 1993, Escribano \& Hidalgo 2000, Thiel et al. 2007) that sustains a very important pelagic fishery (Escribano et al. 2004a) dominated by sardines
(Strangomera bentincki) and anchovies (Engraulis ringens). These fish species utilize nearshore areas around northern Chile for spawning (Rodríguez-Graña \& Castro 2003) and as nurseries (Contreras et al. 2017). This region is also noteworthy because it is characterized by the presence of a unique topographic structure, the Mejillones Peninsula, which separates the coastlines of Mejillones and Antofagasta Bay, oriented to the north and south, respectively. The presence of this topographical feature, combined with interactions between oceanic and atmospheric regional circulation, has enabled the formation of three upwelling centers and shallow zones within this region (Fonseca \& Farías 1987, Escribano \& Hidalgo 2001, Marin et al. 2003, Thiel et al. 2007).

As a result of these particular characteristics, research in this area has emphasized the effects of El Niño events (Rojas et al. 2002), feeding ecology (Rodríguez-Graña et al. 2005), the vertical and offshore distribution of fish larvae (Angel \& Ojeda 2001, Rodríguez-Graña \& Castro 2003, Rojas 2014), larval retention (Rojas \& Landaeta 2014), and the influence of oceanographic conditions on $E$. ringens larvae (Contreras et al. 2017). Information about compositional variations and the abundance of larval fish assemblages in these nearshore areas is currently lacking.

The aim of this study was therefore to evaluate the taxonomic composition and larval fish abundances associated with two nearshore areas in the Mejillones Peninsula during austral autumn-winter season. These data will provide new information about ichthyoplankton community structures in the coastline of northern Chile.

\section{Materials AND METHODS}

\section{STUDY AREA}

The study was performed in two nearshore areas (50 m offshore) around the Mejillones Peninsula within the Antofagasta region: Isla Santa María (ISM; 2326's,

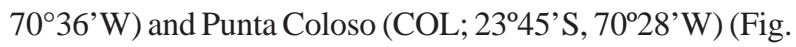
1 ). These nearshore areas are both very shallow (less than $25 \mathrm{~m}$ depth), largely influenced by permanent upwelling and characterized by several oceanographic processes that generate high aggregation and retention of phytoplankton and zooplankton (Escribano \& Hidalgo 2000, Escribano et al. 2004b).

Although the study areas are geographically close to one another, they are markedly different oceanographically. The first, ISM area is a semi-closed 
bay with a central island that is characterized by cold waters with high nutrient content and low surface oxygen levels (Piñones et al. 2007, Pacheco et al. 2011). The ocean bottom in this area includes rocky reefs, barren ground, and kelp forests of Lessonia trabeculata and Macrocystis integrifolia (Ortiz 2008, Jofré-Madariaga et al. 2013, Uribe et al. 2015). In contrast, the COL, is an open coastal area that includes an upwelling plume and a cyclonic eddy in front of the bay (Escribano \& Hidalgo 2001) and an ocean bottom that mainly comprises sand, gravel, and mud (Carrasco 1997, Ortiz et al. 2015) as well as patches of L. trabeculata kelp (Villouta \& Santelices 1986, Ortiz et al. 2010, Jofré-Madariaga et al. 2013).

\section{SAMPLE COLLECTION}

Five surveys were carried out within each area over the 2014 austral autumn-winter season in late-May, mid-June, late-June, mid-July, and at the beginning of August. We collected ichthyoplankton samples using a Bongo net (60 cm mouth diameter, $300 \mu \mathrm{m}$ mesh size) equipped with a TSK flow meter (The Tsurumi-Seiki Co., Ltd., Tsurumi$\mathrm{ku}$, Yokohama, Japan) to quantify filtered water. For each survey, a total of eight consecutive oblique tows at a depth of $10 \mathrm{~m}$ were performed parallel to the coastline between 07:00 and 10:00. An artisanal boat was used for tows that had durations of between 10 and 15 minutes at speeds of 1-2 knots. All samples were fixed in 5\% formalin buffered with sodium borate and then were transferred to 96\% ethanol after $24 \mathrm{~h}$.

All fish larvae were separated, counted, and classified to the lowest possible taxonomic level using previous descriptions presented by Balbontín \& Pérez $(1979,1980)$, Pérez (1979, 1981), Herrera (1984), and Herrera et al. (2007). Fish larvae were categorized according to the adult habitats as epipelagic, demersal, mesopelagic, intertidalsubtidal, or sandy subtidal.

Values for temperature $\left(\mathrm{T} ;{ }^{\circ} \mathrm{C}\right)$, dissolved oxygen (DO; $\mathrm{mg} \mathrm{L}^{-1}$ ), and the salinity (S) of the water column were obtained at the beginning and end of each survey day from the surface to depths between $15 \mathrm{~m}$ and $20 \mathrm{~m}$ using a CTD Seabird SBE-19 plus. Mean values were used for statistical analyses in all cases. Daily prevailing wind data were provided by the Cerro Moreno Meteorological Station $\left(23^{\circ} 27^{\prime} \mathrm{S}, 70^{\circ} 26^{\prime} \mathrm{W}\right)$, a facility that is supervised by the Dirección Meteorológica de Chile. Datasets were downloaded two days prior to each survey for both areas, and values for Ekman transport $\left(E_{t}\right)$ were calculated to assess the effect of wind on the offshore displacement of

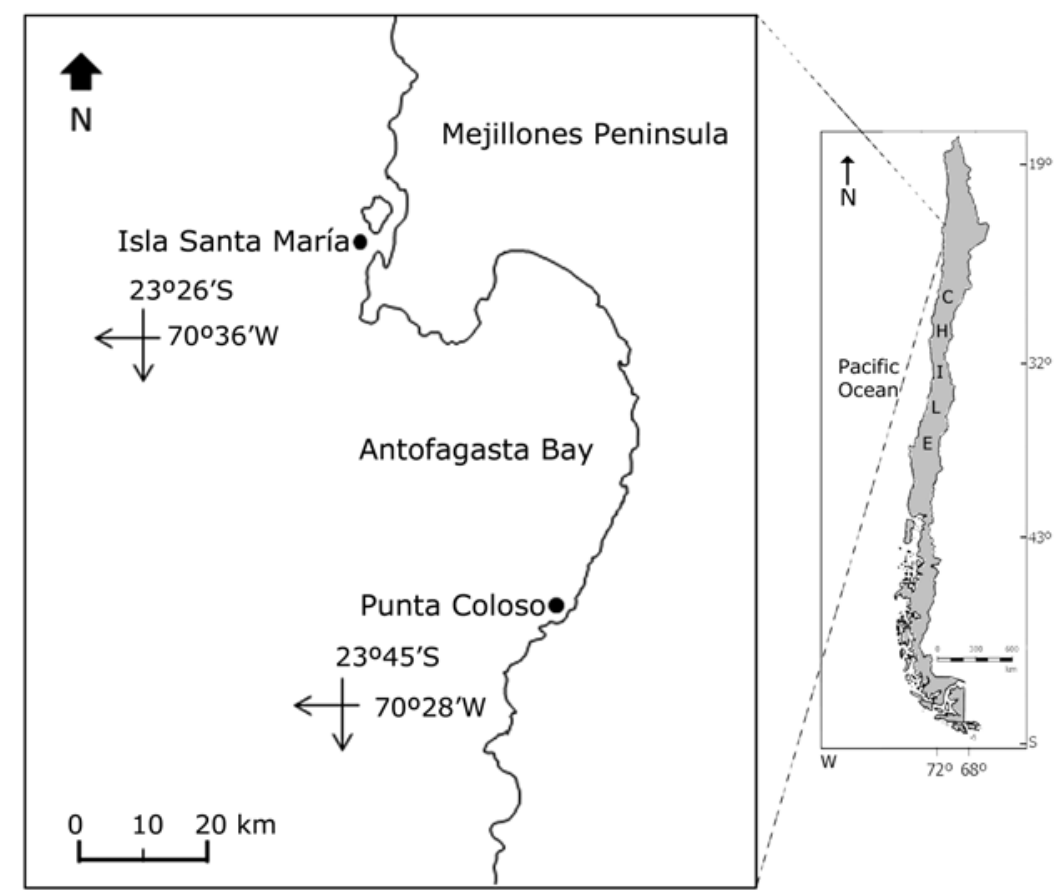

Figure 1. Study area in the northern Chilean coast (southeast Pacific). The black marks on this figure show the surveys areas: Isla Santa María and Punta Coloso / Área de estudio en la costa Norte de Chile (Pacífico Sudeste). Los puntos negros indican las áreas de muestreo: Isla Santa María y Punta Coloso 
surface coastal waters (Mann \& Lazier 2013). The equation used for this calculation is as follows:

$$
\mathrm{M}_{\mathrm{E}}=\tau / \mathrm{f}
$$

In this expression, $M_{E}$ denotes $E_{t}\left(1,000 \mathrm{~kg} \mathrm{~m}^{-1} \mathrm{~s}^{-1}\right)$, while $\mathrm{f}$ is the Coriolis parameter, and $\tau$ is the along-shore wind stress at the water surface (Pond \& Pickard 1983). Similarly, tau $(\tau)$ was estimated as follows:

$$
\tau=\rho_{\mathrm{a}} * \mathrm{C}_{\mathrm{d}} * \mathrm{~W}
$$

In this expression, $\rho_{\mathrm{a}}$ denotes air density $\left(1.2 \mathrm{~kg} \mathrm{~m}^{-3}\right)$, $\mathrm{C}_{\mathrm{d}}$ is the drag coefficient (0.0014), and W refers to alongshore wind speed $\left(\mathrm{m} \mathrm{s}^{-1}\right)$.

\section{Data ANALYsis}

Larval abundances were standardized to individuals (ind.) per $1000 \mathrm{~m}^{-3}$ for each fish species. These data were transformed using the fourth-root to enhance the contribution of less abundant taxa in analyses.

A two-way permutation multivariate analysis of variance (PERMANOVA) was performed using the BrayCurtis index to assess variations in fish larval abundances between areas (ISM-COL) and surveys (May-August). Several similarity percentage analyses (SIMPER) was carried out to compare the contributions of larval fish species between areas and surveys. All analyses were performed using the software package PRIMER V6.1.16 + PERMANOVA (Clarke \& Gorley 2006).

Associations between larval fish abundances and environmental variables were evaluated via canonical redundancy analysis (RDA). A variance inflation factor (VIF) $\leq 10$ was used to reduce multicollinearity among predictive variables and statistical significance was tested using Monte Carlo permutations in the software CANOCO 4.5 (ter Braak \& Šmilauer 2002) using 9,999 iterations.

\section{RESULTS}

\section{FISH LARVAL COMPOSITIONS}

A total of 412,410 fish larvae were collected belonging 22 families and 36 taxa (Table 1). The compositions of larval fish species were different between areas; 21 species representing $27.21 \%$ of the total larval assemblage were collected from the ISM area, while 31 species representing $72.79 \%$ of the total were collected from COL (Table 1). Temporal peaks in species were also different between areas; the species count at ISM was higher in August while that at COL peaked in late-June (Fig. 3).

The results of this study reveal variations in both the abundance and composition of larval fish species belonging to different habitats in both areas. 98.57\% of total larval fish abundance within the ISM area corresponded to intertidalsubtidal species while just $1.43 \%$ corresponded to epipelagic, demersal, mesopelagic, and sandy subtidal species (Fig. 2, Table 1). The most abundant fish species recorded within this area included the triplefin, Helcogrammoides cunninghami (43.9\%), and the labrisomid blenny, Auchenionchus crinitus (36.6\%). Intertidal-subtidal species were also the most dominant group and comprised $57.1 \%$ of the total ISM composition. The remaining $42.9 \%$ of total species

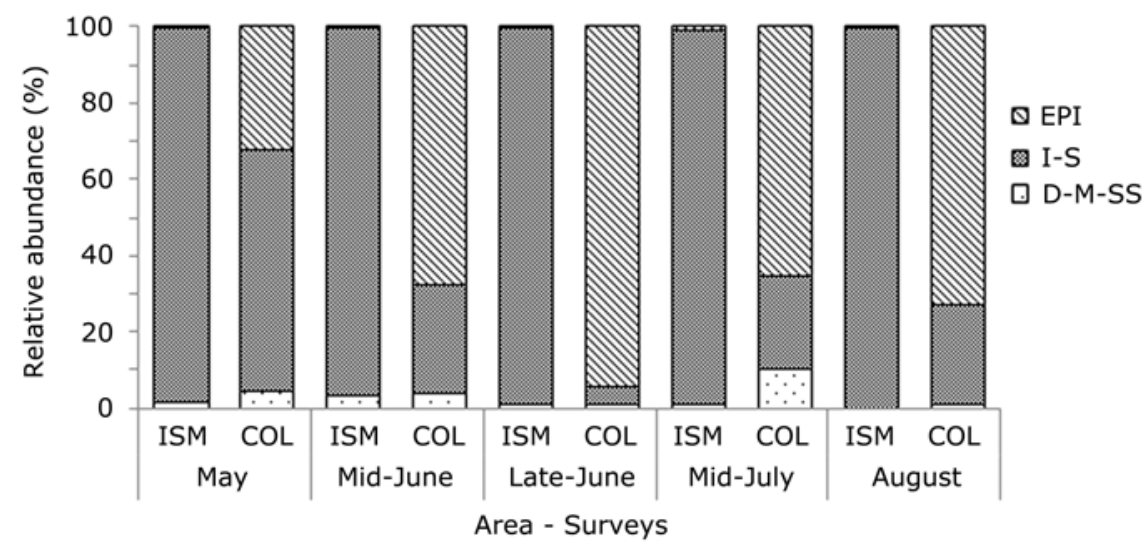

Figure 2. Patterns in fish larvae relative abundances based on adult habitats, including relative abundances per survey (May-August) and area (ISM-COL). Habitats were grouped as: E: epipelagic; I-S: intertidal-subtidal and D-M-S.S.: demersal, mesopelagic and sandy subtidal / Patrones de abundancia relativa de larvas de peces según el hábitat de los peces adultos, incluyendo las abundancias relativas por muestreo (mayo-agosto) y área (ISM-COL). Los hábitats fueron agrupados como: E: epipelágicos, I-S: intermarealessubmareales y D-M-S.S.: demersales, mesopelágicos y de fondos submareales 
Table 1. Taxonomic composition and abundance (ind. $1000 \mathrm{~m}^{-3}$ ) of fish larvae collected in nearshore Isla Santa María (ISM) and Punta Coloso (COL) areas / Composición taxonómica y abundancias (ind. $1000 \mathrm{~m}^{-3}$ ) de las larvas de peces colectadas en las áreas costeras de Isla Santa María (ISM) y Punta Coloso (COL)

\begin{tabular}{|c|c|c|c|c|c|c|c|c|c|}
\hline \multirow{2}{*}{ Family } & \multirow{2}{*}{ Species } & \multirow{2}{*}{$\begin{array}{c}\text { Species } \\
\text { code }\end{array}$} & \multirow{2}{*}{ Habitat } & \multicolumn{3}{|c|}{ ISM } & \multicolumn{3}{|c|}{$\mathrm{COL}$} \\
\hline & & & & Median & Q1 & Q3 & Median & Q1 & Q3 \\
\hline Engraulidae & Engraulis ringens & $\mathrm{Er}$ & $\mathrm{E}$ & 6.09 & 3.25 & 11.59 & 696.95 & 294.78 & 3342.05 \\
\hline Clupeidae & Strangomera bentincki & $\mathrm{Sb}$ & $\mathrm{E}$ & - & - & - & 11.10 & 5.96 & 39.06 \\
\hline \multirow[t]{5}{*}{ Myctophidae } & Hygophum bruuni & $\mathrm{Hb}$ & M & 3.56 & - & - & 20.19 & 10.42 & 30.59 \\
\hline & Lampanyctus iselinoides & $\mathrm{Li}$ & M & - & - & - & 14.29 & 14.29 & 16.72 \\
\hline & Lampanyctus parvicauda & Lp & M & - & - & - & 5.97 & 5.42 & 19.55 \\
\hline & Myctophidae gen.spl & M & M & - & - & - & 6.21 & - & - \\
\hline & Triphoturus oculeus & To & M & - & - & - & 13.09 & 8.30 & 16.72 \\
\hline Merlucciidae & Merluccius gayi & $\mathrm{Mg}$ & $\mathrm{D}$ & - & - & - & 7.99 & - & - \\
\hline Ophidiidae & Genypterus sp. & Gs & $\mathrm{D}$ & - & - & - & 13.94 & 8.30 & 25.45 \\
\hline \multirow[t]{2}{*}{ Gobiesocidae } & Gobiesox marmoratus & $\mathrm{Gm}$ & I-S & 23.32 & 13.81 & 47.69 & 30.59 & 11.83 & 83.59 \\
\hline & Sicyases sanguineus & Ss & $\mathrm{I}-\mathrm{S}$ & 4.14 & 2.96 & 13.40 & 11.93 & 7.05 & 20.11 \\
\hline Atherinopsidae & Odontesthes regia & Or & $\mathrm{E}$ & 10.83 & 3.50 & 17.08 & - & - & - \\
\hline Sebastidae & Sebastes oculatus & So & $\mathrm{D}$ & 9.56 & 4.91 & 20.14 & 22.48 & 10.85 & 30.33 \\
\hline Normanichthyidae & Normanichthys crockeri & $\mathrm{Nc}$ & $\mathrm{E}$ & 4.38 & - & - & 21.48 & 12.58 & 42.45 \\
\hline Agonidae & Agonopsis chiloensis & Ac & $\mathrm{D}$ & 3.12 & - & - & - & - & - \\
\hline Sciaenidae & Sciaenidae gen.spl & $\mathrm{S}$ & S.S. & - & - & - & 7.16 & 6.07 & 11.67 \\
\hline \multirow{2}{*}{ Kyphosidae } & Girella laevifrons & $\mathrm{Gl}$ & I-S & 16.29 & 9.34 & 30.58 & - & - & - \\
\hline & Graus nigra & Gn & I-S & - & - & - & 19.36 & 14.61 & 39.51 \\
\hline Pomacentridae & Chromis crusma & $\mathrm{Cr}$ & $\mathrm{I}-\mathrm{S}$ & - & - & - & 11.83 & 7.38 & 48.87 \\
\hline \multirow[t]{2}{*}{ Pinguipedidae } & Pinguipes chilensis & $\mathrm{Pc}$ & $\mathrm{D}$ & - & - & - & 22.60 & 6.97 & 47.15 \\
\hline & Prolatilus jugularis & $\mathrm{Pj}$ & $\mathrm{D}$ & - & - & - & 21.50 & 15.25 & 47.03 \\
\hline Tripterygiidae & Helcogrammoides cunninghami & $\mathrm{Hc}$ & $\mathrm{I}-\mathrm{S}$ & 348.76 & 99.81 & 720.47 & 19.51 & 9.78 & 35.45 \\
\hline Dactyloscopidae & Sindoscopus australis & $\mathrm{Sa}$ & S.S. & 9.46 & 5.09 & 16.46 & 11.79 & 7.70 & 18.99 \\
\hline \multirow[t]{2}{*}{ Blenniidae } & Hypsoblennius sordidus & $\mathrm{Hs}$ & I-S & 12.02 & 6.42 & 22.69 & 21.26 & 12.42 & 49.68 \\
\hline & Scartichthys viridis & Sv & I-S & 52.62 & 18.43 & 112.76 & 18.50 & 10.85 & 36.65 \\
\hline Clinidae & Myxodes sp. & Ms & $\mathrm{I}-\mathrm{S}$ & 13.77 & 7.86 & 48.76 & - & - & - \\
\hline \multirow[t]{4}{*}{ Labrisomidae } & Auchenionchus crinitus & Acr & I-S & 327.14 & 118.98 & 654.93 & 41.68 & 13.09 & 199.18 \\
\hline & Auchenionchus microcirrhis & $\mathrm{Am}$ & I-S & 26.75 & 11.03 & 54.22 & 154.91 & 47.31 & 469.11 \\
\hline & Calliclinus geniguttatus & $\mathrm{Cg}$ & I-S & 32.50 & 15.12 & 70.64 & 11.92 & 10.08 & 22.60 \\
\hline & Labrisomidae gen.spl & $\mathrm{L}$ & I-S & 3.83 & 3.18 & 5.82 & 111.78 & - & - \\
\hline Gobiidae & Ophiogobius jenynsi & $\mathrm{Oj}$ & I-S & 27.09 & 6.68 & 59.02 & 35.49 & 12.28 & 84.75 \\
\hline Stromateidae & Stromateus stellatus & Ss & $\mathrm{E}$ & - & - & - & 5.96 & - & - \\
\hline \multirow[t]{3}{*}{ Paralichthyidae } & Hippoglossina macrops & $\mathrm{Hm}$ & $\mathrm{D}$ & 5.42 & 4.04 & 6.64 & 22.48 & 7.38 & 39.18 \\
\hline & Paralichthys adspersus & $\mathrm{Pa}$ & S.S. & - & - & - & 17.19 & 10.20 & 29.31 \\
\hline & Paralichthys microps & $\mathrm{Pm}$ & S.S. & - & - & - & 11.83 & 4.95 & 27.94 \\
\hline Syngnathidae & Leptonotus blainvilleanus & $\mathrm{Lb}$ & I-S & 3.83 & - & - & - & - & - \\
\hline Unidentified larvae & & & & 9.66 & 4.50 & 16.6 & 26.12 & 13.11 & 97.13 \\
\hline
\end{tabular}

E: epipelagic, D: demersal, M: mesopelagic, I-S: intertidal-subtidal, S.S.: sandy subtidal

composition comprised taxa from epipelagic (19.05\%), demersal (14.29\%), mesopelagic (4.76\%), and sandy subtidal (4.76\%) habitats, mainly the anchovy E. ringens, the rockfish $S$. oculatus, and the sand stargazer Sindoscopus australis alongside some others (Fig. 2, Table 1).

Data show that species of epipelagic fish (85.49\% of total larval abundance) were the most abundant group recorded within the COL nearshore area, followed by intertidal-subtidal taxa (12.72\%). The remaining 1.79\% corresponded to larval species of demersal, mesopelagic, and sandy subtidal habitats. The most abundant species was the anchovy E. ringens. Intertidal-subtidal taxa comprised $38.72 \%$ of the total composition, dominated by the labrisomid A. microcirrhis. The remaining $61.28 \%$ of species composition comprised demersal (19.35\%), mesopelagic (16.13\%), epipelagic (12.9\%), and sandy subtidal species (12.9\%), a total of 19 taxa including $E$. ringens, Hygophum bruuni, Paralichthys adspersus, and Prolatilus jugularis (Fig. 2, Table 1). 


\section{ENVIRONMENTAL CONDITIONS}

The hydrographic characteristics of the water column ( $T$, $\mathrm{S}$ and DO) varied little between surveys in each area (Fig. 3). The water temperature at ISM remained similar between May and June $\left(14.6 \pm 0.1^{\circ} \mathrm{C}\right)$ but decreased in August $\left(14.0 \pm 0.1^{\circ} \mathrm{C}\right)$ (Fig. $\left.3 \mathrm{~b}\right)$, while the lowest $\mathrm{DO}$ value at this area was recorded in late-June $\left(2.82 \pm 0.27 \mathrm{mg} \mathrm{L}^{-1}\right)$ and the highest in August ( $4.33 \pm 0.22 \mathrm{mg} \mathrm{L}^{-1}$ ) (Fig. 3c). Salinity values also varied little between surveys, from $34.83 \pm$ 0.0005 to $34.95 \pm 0.049$ (Fig. 3d), while $\mathrm{E}_{\mathrm{t}}$ decreased temporally between May and August (507.52 and 210.8 $\mathrm{m}^{3} \mathrm{~s}^{-1} \mathrm{~km}^{-1}$, respectively) (Fig. 3e).

Recorded water temperature at the COL area fluctuated between a minimum of $14.3 \pm 0.1^{\circ} \mathrm{C}$ and a maximum of $15.2 \pm 0.03^{\circ} \mathrm{C}$ (Fig. 3b). The lowest $\mathrm{DO}$ value recorded at this area was in July $\left(1.97 \pm 0.20 \mathrm{mg} \mathrm{L}^{-1}\right)$ while the highest was in August ( $4.34 \pm 0.16 \mathrm{mg} \mathrm{L}^{-1}$ ) (Fig. 3c). Although salinity did not fluctuate much between surveys (34.82 \pm 0.02 and $34.88 \pm 0.01$ ) (Fig. 3d), $\mathrm{E}_{\mathrm{t}}$ peaked during late-Jun $\left(545.48 \mathrm{~m}^{3} \mathrm{~s}^{-1} \mathrm{~km}^{-1}\right)$ and decreased again in August (210.8 $\left.\mathrm{m}^{3} \mathrm{~s}^{-2} \mathrm{~km}^{-1}\right)$ (Fig. 3e).

\section{VARIATION IN FISH LARVAL COMPOSITION}

The results of PERMANOVA tests revealed significant differences in both, abundances and composition between areas and surveys, as well as their interactions (Table 2). At the same time, the results of our SIMPER analysis show that the species $E$. ringens, $H$. cunninghami, A. crinitus, and A. microcirrhis contributed the most to average dissimilarities between areas (Table 3a). The

a)

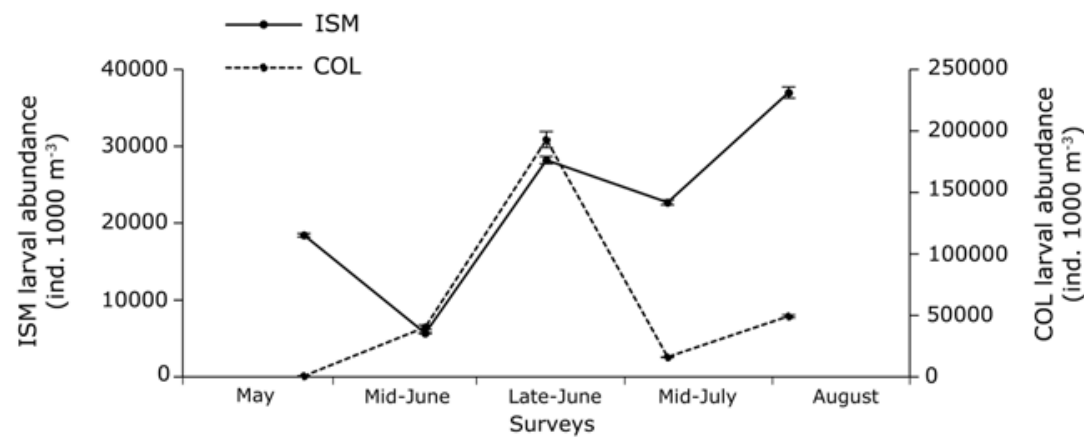

b)

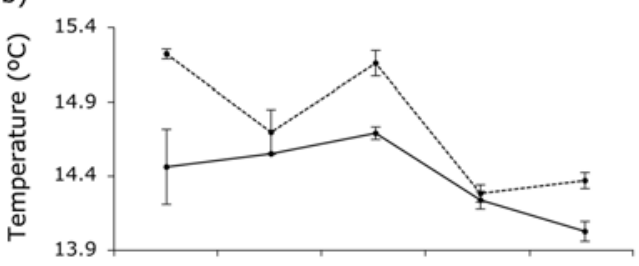

d)

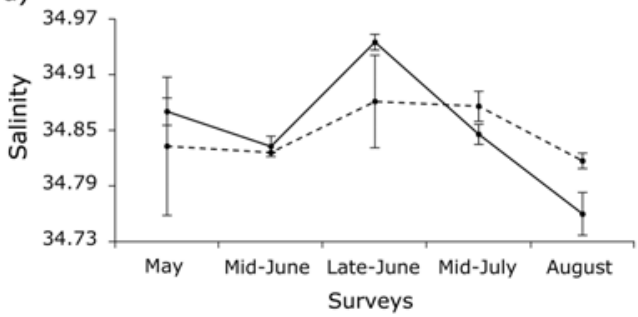

c)

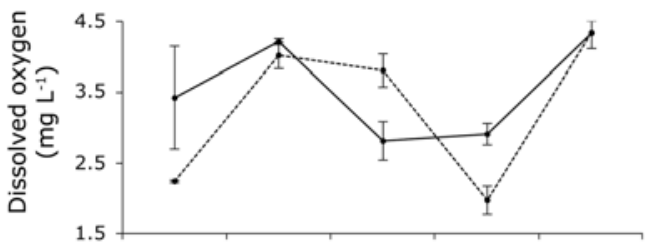

e)

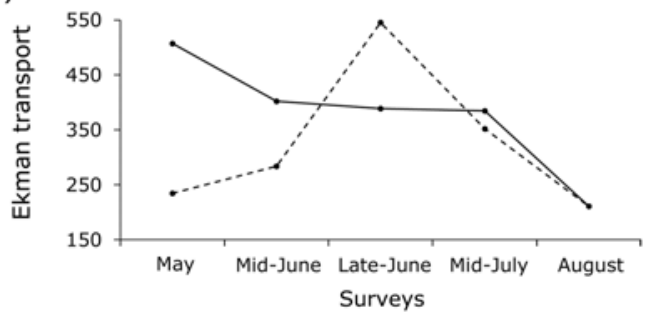

Figure 3. Temporal variations between fish larvae abundances and environmental variables during the study period. The continuous line on this figure marks ISM while the dashed line marks COL for: (a) ISM and COL larval fish abundances, (b) average temperature, (c) average dissolved oxygen, (d) average salinity and (e) Ekman transport per survey (May-August). The vertical lines correspond to standard deviations / Variaciones temporales entre las abundancias de larvas de peces y las variables ambientales durante el periodo de estudio. La línea continua en la figura indica a ISM mientras que la línea discontinua indica a COL, para: (a) abundancias de larvas de peces de ISM y COL, (b) temperatura promedio, (c) oxígeno disuelto promedio (d) salinidad promedio y (e) transporte de Ekman por muestreo (mayo-agosto). Las líneas verticales corresponden a la desviación estándar 
Table 2. PERMANOVA results for similarities in fish larvae abundances between areas (Isla Santa María and Punta Coloso), surveys (MayAugust), and their interactions / Resultados de PERMANOVA por similitud en las abundancias de larvas de peces entre áreas (Isla Santa María y Punta Coloso), muestreos (mayo-agosto) y su interacción

\begin{tabular}{lccccc}
\hline \multicolumn{1}{c}{ Source } & $d f$ & SS & MS & Pseudo-F & $P$ \\
\hline Areas & 4 & 71349 & 71349 & 97.77 & $\mathbf{0 . 0 0 1}$ \\
Surveys & 1 & 32849 & 8212.4 & 11.25 & $\mathbf{0 . 0 0 1}$ \\
Areas x Surveys & 4 & 29245 & 7311.3 & 10.02 & $\mathbf{0 . 0 0 1}$ \\
Residuals & 70 & 51080 & 729.71 & & \\
\hline
\end{tabular}

*df: Degrees of freedom, Pseudo-F: ratios and $P$ : permuted probability values

species $A$. crinitus and $H$. cunninghami contributed the most to dissimilarity within the ISM area (Table $3 b$ ), while E. ringens and A. microcirrhis were the main contributors in the COL area (Table 3c). Additional species that made lower contributions to these areas are also listed in Table 3.
RELATION BETWEEN FisH LARVAL ASSEMBLAgES AND ENVIRONMENTAL VARIABLES

The results of RDA revealed both a good fit and high statistical significance (ISM, $\mathrm{F}_{3,21}=3.605, P<0.005$; COL, $\left.\mathrm{F}_{3,31}=10.38, P<0.001\right)$. Data show that 95.6 and $98.5 \%$ of total variance in fish larval composition was explained by environmental parameters at ISM and COL, respectively. However, salinity was excluded for these comparisons because this variable exhibited strong collinearity with DO. Some species were positively correlated with water temperature and $\mathrm{E}_{\mathrm{t}}$ at ISM, independent of survey (e.g., Myxodes sp., S. oculatus), as well as with DO in both May and mid-June (e.g., C. geniguttatus, Hippoglossina macrops). A number of other species were negatively correlated with temperature and $\mathrm{E}_{\mathrm{t}}$ in August (Sicyases sanguineus, E. ringens, $H$. cunninghami) as well as with DO in mid-July (e.g., Gobiesox marmoratus, Girella laevifrons) (Fig. 4a). a)

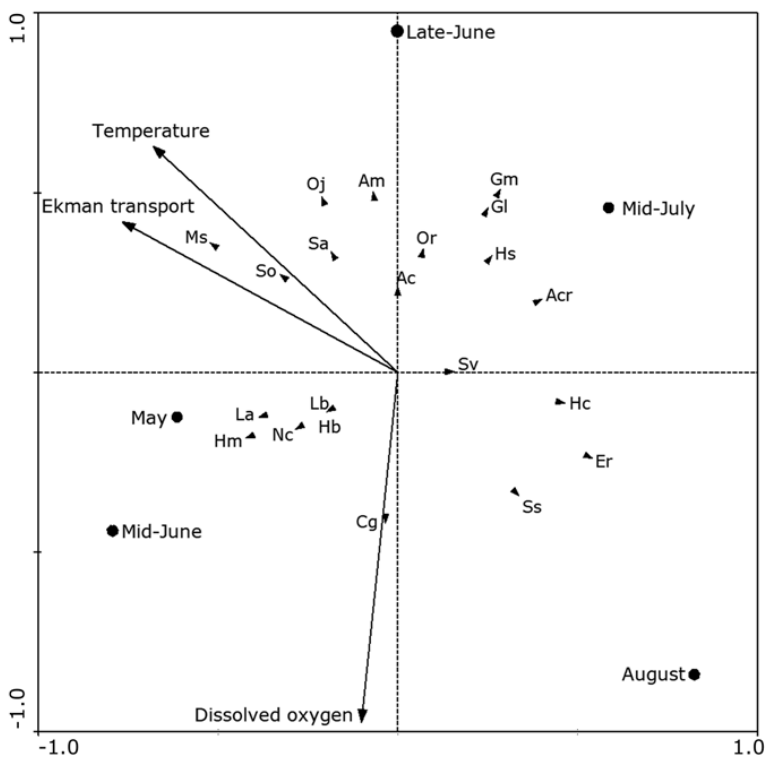

b)

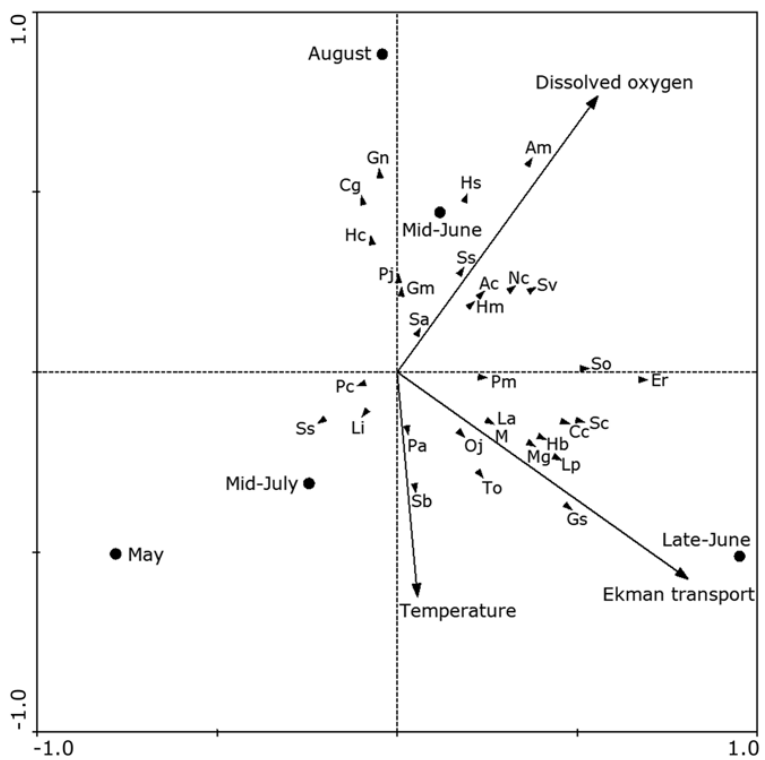

Figure 4. RDA triplot of larval fish assemblages, environmental variables (dissolved oxygen, temperature, and Ekman transport), and surveys at (a) ISM and (b) COL. Fish species are represented by arrows, environmental variables with thick solid arrows, and surveys (May-August) by points. Species codes are given in Table 1 / Triplot del análisis de Redundancia (RDA) del ensamble de larvas de peces, variables ambientales (oxígeno disuelto, temperatura y transporte de Ekman) y muestreos en a) ISM y b) COL. Las especies de peces están representadas por flechas, las variables ambientales por flechas con líneas gruesas, y los muestreos (mayo-agosto) por puntos. Los códigos de las especies se muestran en la Tabla 1 
Table 3. SIMPER results for (a) areas (ISM-COL), (b) ISM, and (c) COL based on average fish larvae abundances. Only species contributing $\mathbf{9 0 \%}$ to average similarity between areas were included in these analyses / Resultados de SIMPER para (a) áreas (ISM-COL), (b) ISM y (c) COL usando las abundancias promedio de larvas de peces. Sólo se incluyeron aquellas especies que contribuyeron en un $90 \%$ de la similitud promedio entre áreas

\begin{tabular}{|c|c|c|c|c|c|c|c|}
\hline & Group & Species & & & & & \\
\hline \multirow{15}{*}{ a) } & \multirow{15}{*}{ ISM \& COL } & & ISM & $\mathrm{COL}$ & & & \\
\hline & & AS $\%: 30.48$ & AA & AA & $\mathrm{AD}$ & $\% \mathrm{Co}$ & $\% \mathrm{Cu}$ \\
\hline & & E. ringens & 0.97 & 54.17 & 22.08 & 31.76 & 31.76 \\
\hline & & H. cunninghami & 30.43 & 1.9 & 11.84 & 17.03 & 48.79 \\
\hline & & A. crinitus & 28.76 & 5.76 & 9.54 & 13.73 & 62.52 \\
\hline & & A. microcirrhis & 6.94 & 20.87 & 5.78 & 8.32 & 70.83 \\
\hline & & A. variolosus & 8.11 & 0.93 & 2.98 & 4.28 & 75.12 \\
\hline & & S. viridis & 8.8 & 3.78 & 2.09 & 3.00 & 78.12 \\
\hline & & N. crockeri & 0.1 & 4.00 & 1.62 & 2.33 & 80.44 \\
\hline & & Myxodes sp. & 3.83 & 0.00 & 1.59 & 2.29 & 82.73 \\
\hline & & O. jenynsi & 5.42 & 1.90 & 1.46 & 2.10 & 84.83 \\
\hline & & S. sanguineus & 0.21 & 2.64 & 1.01 & 1.45 & 86.29 \\
\hline & & P. jugularis & 0.00 & 2.12 & 0.88 & 1.26 & 87.55 \\
\hline & & H. brunni & 0.05 & 2.12 & 0.86 & 1.24 & 88.79 \\
\hline & & P. adspersus & 0.00 & 2.07 & 0.86 & 1.24 & 90.02 \\
\hline \multirow[t]{9}{*}{ b) } & ISM & AS\%: 68.05 & AA & AS & $\% \mathrm{Co}$ & $\% \mathrm{Cu}$ & \\
\hline & & A. crinitus & 28.76 & 19.67 & 28.91 & 28.91 & \\
\hline & & H. cunninghami & 30.43 & 19.19 & 28.2 & 57.11 & \\
\hline & & A. variolosus & 8.11 & 6.19 & 9.09 & 66.20 & \\
\hline & & S. viridis & 8.8 & 5.13 & 7.54 & 73.74 & \\
\hline & & G. marmoratus & 6.4 & 3.48 & 5.11 & 78.85 & \\
\hline & & H. sordidus & 4.68 & 3.18 & 4.68 & 83.53 & \\
\hline & & A. microcirrhis & 6.94 & 3 & 4.41 & 87.94 & \\
\hline & & S. australis & 3.76 & 2.7 & 3.97 & 91.91 & \\
\hline \multirow[t]{11}{*}{ c) } & $\mathrm{COL}$ & AS\%: 42.95 & AA & AS & $\% \mathrm{Co}$ & $\% \mathrm{Cu}$ & \\
\hline & & E. ringens & 54.17 & 17.28 & 40.22 & 40.22 & \\
\hline & & A. microcirrhis & 20.87 & 9.81 & 22.85 & 63.07 & \\
\hline & & G. marmoratus & 5.75 & 2.63 & 6.11 & 69.19 & \\
\hline & & A. crinitus & 5.76 & 1.86 & 4.34 & 73.53 & \\
\hline & & S. viridis & 3.78 & 1.80 & 4.19 & 77.72 & \\
\hline & & S. sanguineus & 2.64 & 1.32 & 3.08 & 80.80 & \\
\hline & & N. crockeri & 4.00 & 1.26 & 2.94 & 83.73 & \\
\hline & & H. sordidus & 3.45 & 1.24 & 2.88 & 86.61 & \\
\hline & & S. australis & 2.94 & 1.13 & 2.64 & 89.25 & \\
\hline & & P. adspersus & 1.48 & 0.59 & 1.38 & 90.63 & \\
\hline
\end{tabular}

AS\%: percentage of average similarity, AA: average abundance, AD: average dissimilarity, AS: average similarity, \%Co: percentage of contribution to the average similarity, \%Cu: percentage of accumulated contribution to the average similarity 
Almost all the species recorded at COL were positively correlated with both $\mathrm{E}_{\mathrm{t}}$ and temperature in late-June (e.g., Genypterus sp., Strangomera bentincki) and with DO in mid-June (e.g., A. microcirrhis, Hypsoblennius sordidus). At the same time, some species exhibited negative correlations with temperature and $\mathrm{E}_{\mathrm{t}}$ in August (Graus nigra, C. geniguttatus, H. cunninghami), as well as with DO in May and mid-July (Pinguipes chilensis, Lampanyctus iselinoides and Sicyases sanguineus) (Fig. 4b).

\section{Discussion}

The results of this study highlight a number of important differences in larval abundances within shallow nearshore areas of the HCS during the austral autumn-winter period. The larval abundances reported here for northern Chile $\left(23^{\circ} \mathrm{S}\right.$ latitude) are higher than those previous recorded during the same season along the central Peruvian coast (14 ${ }^{\circ} \mathrm{S}$ latitude) (Vélez et al. $2005)$ and along the central Chilean coast ( $30^{\circ} \mathrm{S}$ latitude) (Hernández-Miranda et al. 2003, Landaeta et al. 2015). The key phenomenon responsible for the higher biological productivity of the HCS is coastal upwelling (Montecino \& Lange 2009); indeed, the high ichthyoplankton abundance of nearshore northern Chile compared with other HCS regions could by a consequence of the very narrow continental shelf (less than $20 \mathrm{~km}$ wide) in this region. These features enable permanent upwelling within the coastal zone and lead to incremental levels of biomass and productivity throughout the year (Fonseca \& Farias 1987, Morales et al. 1996, Daneri et al. 2000, Escribano et al. 2004b, Letelier et al. 2012). This also means that changes in upwelling conditions in northern Chile are less pronounced than those at other HCS latitudes where differences in peak fish larvae abundances are strongly coupled to spawning and short-term oceanographic events (HernándezMiranda et al. 2003).

Fish larvae assemblages are very similar between central and northern Chile; 5 species are found just in northern Chile (Lampanyctus parvicauda, Agonopsis chiloensis, G. nigra, C. geniguttatus, and Ophiogobius jenynsi) and another 13 occur just in the central part of the country (e.g., Bovichthys chilensis, A. variolosus, Helcogrammoides chilensis). At the same time, Peru and northern Chile share just 8 common species (e.g., E. ringens, G. marmoratus, Normanichthys crockeri). Species variation between regions might be the result of biogeographic processes. The HCS is a large marine ecosystem and each distinct regions are influenced by different water masses that predominate at different latitudes with different characteristics; fresh, cooler, and less saline surface water predominates in northern and, principally in central Chile
(sub-Antarctic surface water, Antarctic intermediate water), while warmer and more saline waters are seen around central Peru (subtropical surface water, equatorial subsurface water) (Silva 1977, Silva \& Neshyba 1980). These water masses influence the biotic and abiotic characteristics of each region, largely determining the composition of fish larvae in nearshore areas.

Species of Engraulidae, Tripterygiidae, Labrisomidae, Gobiesocidae, Blenniidae, and Gobiidae families were dominant in both sample areas, in agreement with previous studies on the HCS that have demonstrated the presence of similar groups at high abundance in nearshore shallow waters around the central coasts of Peru and Chile (Hernández-Miranda et al. 2003, Vélez et al. 2005, Landaeta et al. 2015, Díaz-Astudillo et al. 2017). The families recorded in this study have also been noted in other current systems, including the Canarias Current System (Azeiteiro et al. 2006, Beldade et al. 2006, Álvarez et al. 2015), the Australia East Current System, and the Equatorial North Current System (Leis \& Miller 1976, Kingsford \& Choat 1989, Gray 1993), as well as in shallow nearshore waters within the Agulhas Current (Rabbaniha et al. 2015). These similarities not only result from similar reproductive behaviors, but also suggest that these fish species require the same resources during early life stages (Nonaka et al. 2000). Independent of habitat (e.g., epipelagic, intertidal), fish species spawn in, or near to, coastal habitats in order to avail of a suitable food supply, shelter, and favorable ecophysiological conditions for larval development (Blaber \& Blaber 1980, Pattrick \& Strydom 2014). Indeed, by taking advantage of the optimal conditions offered by these habitats, adults increase the probability of survival and development of their offspring and therefore influence the ichthyoplankton abundance and composition of nearshore areas (Houde \& Zastrow 1993, Castro \& Hernandez 2000).

The data presented in this study show that larval compositions were different between areas, as well as the presence of a marked difference in the dominance of inshore and offshore larval species. The ISM area was characterized by the highest abundance of intertidal-subtidal fish species (e.g., $H$. cunninghami and A. crinitus), those that develop and settle on the seabed; this result suggests that such species permanently utilize this area, independent of seasonal shifts over short timescales. A high abundance of inshore habitat fish species is also characteristic of other nearshore ecosystems around the world (Borges et al. 2007, Álvarez et al. 2015, Isari et al. 2017), and is indicative of interactions between biophysical mechanisms that cause taxa to remain within their natal areas (Sponaugle et al. 2002, Vélez et al. 2005). This means that features such as coastal geomorphology, ocean bottom topography, 
and the presence of kelp forests might be reducing circulation patterns at ISM. These attributes also decrease the probability of offshore transport and contribute to larval retention, especially for species that develop in nearshore areas (Cowen 2002, Kingsford et al. 2002, Largier 2003, Palma et al. 2006).

Offshore larval species classified as epipelagic were the most abundant and dominant at the COL area. The fact that the epipelagic anchovy (E. ringens), a species with a life cycle that takes place in the water column, was most abundant at this area likely reflects the fact that adult fish use nearshore regions as nursery areas because of high productivity and low offshore transport. A number of previous studies have noted that E. ringens preferentially spawns during the austral winter (Bernal et al. 1983, Loeb \& Rojas 1988, Castro \& Hernandez 2000, Hernández \& Castro 2000), especially in zones that are characterized by highly variable short-term processes (e.g., upwelling-relaxation) and favorable oceanographic and meteorological conditions (Rojas et al. 2002, Rojas \& Landaeta 2014). High abundances of E. ringens larvae are common in other nearshore areas within the HCS (Hernández-Miranda et al. 2003, Vélez et al. 2005, Landaeta et al. 2015), while larval fish from the Engraulidae occur frequently in other ecosystems of this type (Able et al. 2010, Pattrick \& Strydom 2014, Giordano et al. 2015). Thus, use of the COL nearshore area for spawning might be a tactic to increase larval survival as this region is characterized by the high retention of planktonic organisms and food availability (Escribano \& Hidalgo 2000, 2001, Escribano et al. 2004b).

The environmental features measured in this study remained relatively constant throughout the austral autumn-winter season. However, our results did reveal association differences between larval assemblages and short-term oceanographic features between both areas. Several species in our dataset were strongly correlated with high DO levels (e.g., A. microcirrhis, C. genigutattus), warmer temperate waters, and strong $\mathrm{E}_{\mathrm{t}}$ values (e.g., Myxodes sp., S. oculatus); indeed, the fact that rarer species were negatively correlated with the same parameters (e.g., G. nigra, E. ringens, S. sanguineus), suggests aggregation with cooler water temperatures, lower $E_{t}$ values, and higher oxygen waters.

Temperature is one of the most important environmental factors that influence the metabolism, growth, and development of ichthyoplankton (Munday et al. 2008). For example, a high temperature close to the tolerance limit of a species will increase metabolic costs and limit the energy available for growth (Pörtner \& Peck 2010), particularly during periods of short-term temperature variability, where also several biochemical indices (e.g., lipids, protein synthesis) may influence natural coastal fish populations (Duarte et al. 2018). In other words, this suggest that species correlated with high or low water temperatures could have different thermal requirements or preferences in both their metabolism and growth during early fish stages (Houde 1989, Pepin 1991).

Similarly, variations in DO influences the growth of larval fish species over the long-term and reduces their probability of survival (Vanderplancke et al. 2015). The correlation reported here between larval species and high DO rates might also reflect a strategy of spawning during optimal conditions due to low DO rates can cause conditions of stress for spawning fish and their eggs (Beitinger 1990). This is because are significantly less tolerant to low oxygen levels compared with their adult counterparts (Zeng et al. 2010, Gilly et al. 2013, Sloterdijk et al. 2017).

Favorable $\mathrm{E}_{\mathrm{t}}$ conditions are also related to nutrient influx into superficial waters near to coasts (HernandezMiranda et al. 2003). Plankton accumulation provides a key potential food source and is therefore beneficial for larval survival, another reason why fish species could evolved their spawning behaviors in these areas (Tiedemann \& Brehmer 2017). The presence of several species correlated with $E_{t}$ values suggests a reproductive strategy which might also act as a coupled life history mechanism in several species (Cushing 1990).

Although the HCS is extremely important, surprisingly little information about the ecology of fish larvae in nearshore habitats is currently available. Most research in Chile has focused on the central parts of the country (Hernández-Miranda et al. 2003, Landaeta et al. 2015, DíazAstudillo et al. 2017); this study therefore presents the first evidence of spatial and temporal variation in fish larval assemblages in nearshore northern latitudes. We have demonstrated the presence of high abundances of fish larvae in two shallow nearshore areas in north coast of Chile compared with other geographical areas encompassed by the HCS. Irrespective of the processes that underlie these variations, further detailed studies will be required to better understand the ecology of fish larvae across northern Chile. This study highlights a number of intriguing new possibilities that might explain variations in ichthyoplankton abundances in other HCS nearshore areas (Mejillones Peninsula). 


\section{ACKNOWLEDGEMENTS}

We wish to thank an anonymous reviewer for taking the time to evaluate this manuscript and for providing us with a number of constructive comments. FONDECYT 1150296 for English revision of this manuscript. This study was funded by project grant FONDECYT 1120868 (to MTG and MFL).

\section{LITERATURE CITED}

Able KW, DH Wilber, A Muzeni-Corino \& DG Clarke. 2010. Spring and summer larval fish assemblages in the surf zone and nearshore off Northern New Jersey, USA. Estuaries and Coasts 33: 211-222.

Adkins ME, CA Simpfendorfer \& AJ Tobin. 2016. Large tropical fishes and their use of the nearshore littoral, intertidal and subtidal habitat mosaic. Marine and Freshwater Research 67: 1534-1545.

Álvarez I, IA Catalán, A Jordi \& F Alemany. 2015. Interaction between spawning habitat and coastally steered circulation regulate larval fish retention in a large shallow temperate bay. Estuarine, Coastal and Shelf Science 167: 377-389.

Angel A \& FP Ojeda. 2001. Structure and trophic organization of subtidal fish assemblages on the northern Chilean coast: the effect of habitat complexity. Marine Ecology Progress Series 217: 81-91.

Ayon P, G Swartzman, P Espinoza \& A Bertrand. 2011. Long-term changes in zooplankton size distribution in the Peruvian Humboldt Current System: conditions favoring sardine or anchovy. Marine Ecology Progress Series 422: 211-222.

Azeiteiro UM, L Bacelar-Nicolau, P Resende, F Gonçalves \& MJ Pereira. 2006. Larval fish distribution in shallow coastal waters off North Western Iberia (NE Atlantic). Estuarine, Coastal and Shelf Science 69(3-4): 554-566.

Balbontín F \& R Pérez. 1979. Modalidad de postura, huevos y estados larvales de Hypsoblennius sordidus (Bennett) en la bahía de Valparaíso (Blenniidae: Perciformes). Revista de Biología Marina 16: 311-318.

Balbontín F \& R Pérez. 1980. Descripción de los estados larvales de Normanichthys crockeri Clark (Perciformes: Normanichthyidae) del área de Valparaíso. Revista de Biología Marina 17: 81-95.

Beitinger TL. 1990. Behavioral reactions for the assessment of stress in fishes. Journal of Great Lakes Research 16(4): 495-528.

Beldade R, R Borges \& EJ Gonçalves. 2006. Depth distribution of nearshore temperate fish larval assemblages near rocky substrates. Journal of Plankton Research 28(11): 1003-1013.

Bernal PA, FL Robles \& O Rojas. 1983. Variabilidad física y biológica en la región meridional del sistema de corrientes Chile-Perú. FAO Fisheries Report 291: 683-711.
Blaber SJM \& TG Blaber. 1980. Factors affecting the distribution of juvenile estuarine and inshore fish. Journal of Fish Biology 17: 143-162.

Borges R, R Ben-Hamadou, MA Chícharo, P Ré \& EJ Gonçalves. 2007. Horizontal spatial and temporal distribution patterns of nearshore larval fish assemblages at a temperate rocky shore. Estuarine, Coastal and Shelf Science 71: 412-428.

Braak CJF ter \& P Smilauer. 2002. CANOCO reference manual and CanoDraw for Windows user's guide: software for canonical community ordination. (Version 4.5). $<$ www.canoco.com>.

Bustos CA, MF Landaeta \& F Balbontín. 2008. Spawning and early nursery areas of anchoveta Engraulis ringens Jenyns, 1842 in fjords of southern Chile. Revista de Biología Marina y Oceanografía 43(2): 381-389.

Carrasco FD. 1997. Sublittoral macrobenthic fauna off Punta Coloso, Antofagasta, northern Chile: high persistence of the polychaete assemblage. Bulletin of Marine Science 60(2): 443-459.

Castro LR \& EH Hernández. 2000. Early life survival of the anchoveta Engraulis ringens off central Chile during the 1995 and 1996 winter spawning seasons. Transactions of the American Fisheries Society 129(5): 1107-1117.

Castro LR, GR Salinas \& EH Hernández. 2000. Environmental influences on winter spawning of the anchoveta Engraulis ringens off central Chile. Marine Ecology Progress Series 197: 247-258.

Chavez FP \& M Messié. 2009. A comparison of Eastern Boundary Upwelling Ecosystems. Progress in Oceanography 83: 80-96.

Clarke KR \& RN Gorley. 2006. PRIMER v6: User Manual/ Tutorial. PRIMER-E, Plymouth.

Contreras JE, C Rodríguez-Valentino, MF Landaeta, G Plaza, MI Castillo \& M Alvarado-Niño. 2017. Growth and mortality of larval anchoveta Engraulis ringens, in northern Chile during winter and their relationship with coastal hydrographic conditions. Fisheries Oceanography 1: 12 .

Cowen RK. 2002. Larval dispersal and retention and consequences for population connectivity. In: Sale PF (ed). Coral reef fishes: Dynamics and diversity in a complex ecosystem, pp. 149-170. Academic Press, San Diego.

Cushing DH. 1990. Plankton production and year-class strength in fish populations: an update of the match/ mismatch hypothesis. Advances in Marine Biology 26: 249293.

Daneri G, V Dellarossa, R Quiñones, B Jacob, P Montero \& O Ulloa. 2000. Primary production and community respiration in the Humboldt Current System off Chile and associated oceanic areas. Marine Ecology Progress Series 12: 41-49. 
Díaz-Astudillo M, MI Castillo, MA Cáceres, G Plaza \& MF Landaeta. 2017. Oceanographic and lunar forcing affects nearshore larval fish assemblages from temperate rocky reefs. Marine Biology Research 13(10): 1015-1026.

Duarte I, RP Vasconcelos, S França, MI Batista, T Susanne, HN Cabral \& VF Fonseca. 2018. Short-term variability of fish condition and growth in estuarine and shallow coastal areas. Marine Environmental Research 134: 130-137.

Escribano R \& P Hidalgo. 2000. Spatial distribution of copepods in the north of the Humboldt Current region off Chile during coastal upwelling. Journal of the Marine Biological Association of the United Kingdom 80: 283-290.

Escribano R \& P Hidalgo. 2001. Circulación inducida por el viento en la Bahía de Antofagasta, norte de Chile (23으). Revista de Biología Marina 36(1): 43-60.

Escribano R, G Daneri, L Farías, VA Gallardo, HE González, D Gutiérrez, CB Lange, CE Morales, O Pizarro, O Ulloa \& M Braun. 2004a. Biological and chemical consequences of the 1997-1998 El Niño in the Chilean coastal upwelling system: A synthesis. Deep-Sea Research, Part II 51: 2389-2411.

Escribano R, SA Rosales \& JL Blanco. 2004b. Understanding upwelling circulation off Antofagasta (northern Chile): A three-dimensional numerical-modeling approach. Continental Shelf Research 24: 37-53.

Fonseca TR \& M Farías. 1987. Estudios de los procesos de surgencia en la costa chilena utilizando percepción remota. Investigación Pesquera 34: 33-46.

Gilly WF, JM Beman, SY Litvin \& BH Robison. 2013. Oceanographic and biological effects of shoaling of the oxygen minimum zone. Annual Review of Marine Science 5: 393-420.

Giordano D, A Profeta, B Busalacchi, R Minutoli, L Guglielmo, A Bergamasco \& A Granata. 2015. Summer larval fish assemblages in the Southern Tyrrhenian Sea (Western Mediterranean Sea). Marine Ecology 36: 104-117.

Gray CA. 1993. Horizontal and vertical trends in the distributions of larval fishes in coastal waters off central New South Wales, Australia. Marine Biology 116(4): 649-666.

Hernández EH \& LR Castro. 2000. Larval growth of the anchoveta Engraulis ringens during the winter spawning season off central Chile. Fishery Bulletin 98(4): 704-704.

Hernández-Miranda E, AT Palma \& FP Ojeda. 2003. Larval fish assemblages in nearshore coastal waters off central Chile: temporal and spatial patterns. Estuarine, Coastal and Shelf Science 56: 1075-1092.

Herrera G. 1984. Descripción de estados post-embrionales de Ophiogobius jenynsi Hoese 1976 (Gobiidae: Blennioidei). Revista de Biología Marina 20: 159-168.

Herrera G, A Llanos-Rivera \& MF Landaeta. 2007. Larvae of the sand stargazer Sindoscopus australis and notes on the development of Dactyloscopidae (Perciformes: Blennioidei). Zootaxa 1401: 63-68.
Houde ED. 1989. Comparative growth, mortality, and energetics of marine fish larvae: temperature and implied latitudinal effects. Fishery Bulletin 87(3): 471-495.

Houde ED \& CE Zastrow. 1993. Ecosystem-and taxon-specific dynamic and energetics properties of larval fish assemblages. Bulletin of Marine Science 53(2): 290-335.

Isari S, JK Pearman, L Casas, CT Michell, J Curdia, ML Berumen \& X Irigoien. 2017. Exploring the larval fish community of the central Red Sea with an integrated morphological and molecular approach. Plos ONE 12(8): e0182503. < https://doi.org/10.1371/journal.pone.0182503>

Jofré-Madariaga D, M Ortiz \& M Thiel. 2013. Demography and feeding behavior of the kelp crab Taliepus marginatus in subtidal habitats dominated by the kelps Macrocystis pyrifera or Lessonia trabeculata. Invertebrate Biology 132(2): 133-144.

Johnson-Colegrove A, L Ciannelli \& RD Brodeur. 2015. Ichthyoplankton distribution and abundance in relation to nearshore dissolved oxygen levels and other environmental variables within the Northern California Current System. Fisheries Oceanography 24(6): 495-507.

Kingsford MJ \& JH Choat. 1989. Horizontal distribution patterns of presettlement reef fish: are they influenced by the proximity of reefs? Marine Biology 101(3): 285-297.

Kingsford MJ, JM Leis, A Shanks, KC Lindeman, SG Morgan \& J Pineda. 2002. Sensory environments, larval abilities and local self-recruitment. Bulletin of Marine Science 70(1): 309-340.

Landaeta MF \& LR Castro. 2006. Spawning and larval survival of the Chilean hake Merluccius gayi under later summer conditions in the Gulf of Arauco, central Chile. Fisheries Research 77: 115-121.

Landaeta MF, F Zavala-Muñoz, P Palacios-Fuentes, CA Bustos, M Alvarado-Niño, J Letelier, MA Cáceres \& G Muñoz. 2015. Spatial and temporal variations of coastal fish larvae, ectoparasites and oceanographic conditions off central Chile. Revista de Biología Marina y Oceanografía 50(3): 563-574.

Largier JL. 2003. Considerations in estimating larval dispersal distance from oceanographic data. Ecological Applications 13(1): 71-89.

Leis JM \& JM Miller. 1976. Offshore distributional patterns of Hawaiian fish larvae. Marine Biology 36(4): 359-367.

Letelier J, L Soto-Mardones, S Salinas, L Vincenti, R Pavez \& M Arriagada. 2012. Influencia de la península de Mejillones en la variabilidad oceanográfica anual e interanual frente al norte de Chile. Revista de Biología Marina Oceanografía 47(3): 513-526.

Loeb VJ \& O Rojas. 1988. Interannual variation of ichthyoplankton composition and abundance relations off northern Chile, 1964-83. Fishery Bulletin 86(1): 1-24.

Mann KH \& JRN Lazier. 1991. Dynamics of marine ecosystems: biological-physical interactions in the oceans, 496 pp. Blackwell Publishing, Oxford. 
Mann KH \& JRN Lazier. 2013. Fronts in coastal waters. In: Mann KH \& JRN Lazier (eds). Dynamics of marine ecosystems, pp. 216-253. John Wiley \& Sons, Oxford.

Marín VH, LE Delgado \& R Escribano. 2003. Upwelling shadows at Mejillones Bay (northern Chilean coast): a remote sensing in situ analysis. Investigaciones Marinas 31(2): 47-55.

Montecino V \& CB Lange. 2009. The Humboldt Current System: Ecosystem components and processes, fisheries, and sediment studies. Progress in Oceanography 83(1-4): 65-79.

Morales CE, JL Blanco, M Braun, H Reyes \& N Silva. 1996. Chlorophyll- $a$ distribution and associated oceanographic conditions in the upwelling region off northern Chile during the winter and spring 1993. Deep Sea Research Part I: Oceanographic Research Papers 43(3): 267-289.

Munday PL, MJ Kingsford, M O'Callaghan \& JM Donelson. 2008. Elevated temperature restricts growth potential of the coral reef fish Acanthochromis polyacanthus. Coral Reefs 27(4): 927-931.

Nonaka RH, Y Matsuura \& K Suzuki. 2000. Seasonal variation in larval fish assemblages in relation to oceanographic conditions in the Abrolhos Bank region off eastern Brazil. Fishery Bulletin 98(4): 767-784.

Olivar P, M Emelianov, F Villate, I Uriarte, F Maynou, I Álvarez \& E Morote. 2010. The role of oceanographic conditions and plankton availability in larval fish assemblages off the Catalan coast (NW Mediterranean). Fisheries Oceanography 19(3): 209-229.

Olivar P, A Sabatés, MV Pastor \& JL Pelegrí. 2016. Water masses and mesoscale control on latitudinal and cross-shelf variations in larval fish assemblages off NW Africa. DeepSea Research I 117: 120-137.

Ortiz M. 2008. Mass balanced and dynamic simulations of trophic models of kelp ecosystems near the Mejillones Peninsula of northern Chile (SE Pacific): comparative network structure and assessment of harvest strategies. Ecological Modelling 216: 31-46.

Ortiz M, M Avendaño, M Cantillañez, F Berrios \& L Campos. 2010. Trophic mass balanced models and dynamic simulations of benthic communities from La Rinconada Marine Reserve off northern Chile: network properties and multispecies harvest scenario assessment. Aquatic Conservation 20(1): 58-73.

Ortiz M, F Berrios, L Campos, R Uribe, A Ramírez, B Hermosillo-Núñez, J González \& F RodríguezZaragoza. 2015. Mass balanced trophic models and shortterm dynamical simulations for benthic ecological systems of Mejillones an Antofagasta bays (SE Pacific): Comparative network structure and assessment of human impacts. Ecological Modelling 309-310: 153-162.

Pacheco AS, MT González, J Bremner, M Oliva, O Heilmayer, J Laudien \& JM Riascos. 2011. Functional diversity of marine macrobenthic communities from sublittoral soft-sediment habitats off northern Chile. Helgoland Marine Research 65: 413-424.
Palma AT, LM Pardo, R Veas, C Cartes, M Silva, K Manríquez, A Díaz, C Muñoz \& FP Ojeda. 2006. Coastal brachyuran decapods: settlement and recruitment under contrasting coastal geometry conditions. Marine Ecology Progress Series 316: 139-153.

Paris C \& RK Cowen. 2004. Direct evidence of a biophysical retention mechanism for coral reef fish larvae. Limnology Oceanography 49(6): 1964-1979.

Pattrick P \& NA Strydom. 2014. Larval fish variability in response to oceanographic features in a nearshore nursery area. Journal of Fish Biology 85: 857-881.

Pepin P. 1991. Effect of temperature and size on development, mortality, and survival rates of the pelagic early life history stages of marine fish. Canadian Journal of Fisheries and Aquatic Sciences 48(3): 503-518.

Pérez R. 1979. Desarrollo postembrionario de Tripterygion chilensis (Cancino 1955), en la bahía de Valparaíso (Tripterygiidae: Perciformes). Revista de Biología Marina 16: 319-329.

Pérez R. 1981. Desarrollo embrionario y larval de los pejesapos Sycyases sanguineus y Gobiesox marmoratus en la bahía de Valparaíso, Chile, con notas sobre su reproducción (Gobiesocidae: Pisces). Investigaciones Marinas 9: 1-24.

Piñones A, JC Castilla, R Guiñez \& JL Largier. 2007. Nearshore surface temperatures in Antofagasta Bay (Chile) and adjacent upwelling centers. Ciencias Marinas 33(1): 3748.

Pond S \& GL Pickard. 1983. Introductory dynamical oceanography, 329 pp. Butterworth-Heinemann, Talley.

Pörtner HO \& MA Peck. 2010. Climate change effects on fishes and fisheries: towards a cause-and-effect understanding. Journal of Fish Biology 77(8): 1745-1779.

Rabbaniha M, JC Molinero, L López-López, J Javidpour, AL Primo, F Owfi \& U Sommer. 2015. Habitat association of larval fish assemblages in the northern Persian Gulf. Marine Pollution Bulletin 97: 105-110.

Rodríguez-Graña L \& LR Castro. 2003. Ichthyoplankton distribution off the Peninsula de Mejillones, Chile $\left(23^{\circ} \mathrm{S}, 71^{\circ} \mathrm{W}\right)$, under variable hydrographic conditions during the austral summer and winter of the 1997 El Niño. Hydrobiologia 501: 59-73.

Rodríguez-Graña L, L Castro, M Loureiro, HE González \& D Calliari. 2005. Feeding ecology of dominant larval myctophids in an upwelling area of the Humboldt Current. Marine Ecology Progress Series 290: 119-134.

Rojas PM. 2014. Diel variation in the vertical distribution of fish larvae forced by upwelling filaments off Punta Angamos (northern Chile). Latin American Journal of Aquatic Research 42(3): 401-417.

Rojas PM \& MF Landaeta. 2014. Fish larvae retention linked to abrupt bathymetry at Mejillones Bay (northern Chile) during coastal upwelling events. Latin American Journal of Aquatic Research 42(5): 989-1008.

Rojas PM, R Escribano \& VH Marín. 2002. Fish larvae distribution off Mejillones Peninsula (northern Chile) during 
a coastal upwelling event in Spring 1999: interaction with the cold upwelling plume. Fisheries Oceanography 11(4): 233-244.

Silva N. 1977. Water mass structure and circulation off southern Chile. Master Thesis, School of Oceanography, Oregon State University, Corvallis, 83 pp. [partially published]

Silva N \& S Neshyba. 1980. Masas de agua y circulación geostrófica frente a la costa de Chile Austral. Serie Científica, Instituto Antártico Chileno 25/26: 5-32.

Sloterdijk H, P Brehmer, O Sadio, H Müller, J Döring \& W Ekau. 2017. Composition and structure of the larval fish community related to environmental parameters in a tropical estuary impacted by climate change. Estuarine, Coastal and Shelf Science 197: 10-26.

Smith KA \& IM Suthers. 1999. Displacement of diverse ichthyoplankton assemblages by a coastal upwelling event on the Sydney shelf. Marine Ecology Progress Series 176: 49-62.

Sponaugle S, RK Cowen, A Shanks, SG Morgan, JM Leis, J Pineda, GW Boehlert, MJ Kingsford, KC Lindeman, C Grimes \& JL Munro. 2002. Predicting self-recruitment in marine populations: biophysical correlates and mechanisms. Bulletin of Marine Science 70(1): 341-375.

Strydom NA. 2003. Occurrence of larval and early juvenile fishes in the surf zone adjacent to two intermittently open estuaries, South Africa. Environmental Biology of Fishes 66: 349-359.

Thiel M, EC Macaya, E Acuna, WE Arntz, H Bastias, K Brokordt, PA Camus, JC Castilla, LR Castro, M Cortes \& CP Dumont. 2007. The Humboldt Current System of northern and central Chile: oceanographic processes, ecological interactions and socioeconomic feedback. Oceanography and Marine Biology: An Annual Review 45: 195-344.
Tiedemann M \& P Brehmer. 2017. Larval fish assemblages across an upwelling front: Indication for active and passive retention. Estuarine, Coastal and Shelf Science 187: 118133.

Uribe RA, M Ortiz, EC Macaya \& AS Pacheco. 2015. Successional patterns of hard-bottom macrobenthic communities at kelps bed (Lessonia trabeculata) and barren ground sublittoral systems. Journal of Experimental Marine Biology and Ecology 472: 180-188.

Vanderplancke G, G Claireaux, P Quazuguel, L Madec, S Ferraresso, A Sévère, JL Zambonino-Infante \& D Mazurais. 2015. Hypoxic episode during the larval period has long-term effects on European sea bass juveniles (Dicentrarchus labrax). Marine Biology 162(2): 367-376.

Vélez JA, W Watson, W Arntz, M Wolff \& SB SchnackSchiel. 2005. Larval fish assemblages in Independencia Bay, Pisco, Peru: temporal and spatial relationships. Marine Biology 147: 77-91.

Villouta E \& B Santelices. 1986. Estructura de la comunidad submareal de Lessonia (Phaeophyta, Laminariales) en Chile norte y central. Revista Chilena de Historia Natural 57: 111122.

Yannicelli B, LR Castro, A Valle-Levinson, L Atkinson \& D Figueroa. 2006. Vertical distribution of decapod larvae in the entrance of an equatorward facing bay of central Chile: implications for transport. Journal of Plankton Research 28(1): 19-37.

Zeng LQ, YG Zhang, ZD Cao \& SJ Fu. 2010. Effect of temperature on excess post-exercise oxygen consumption in juvenile southern catfish (Silurus meridionalis Chen) following exhaustive exercise. Fish Physiology and Biochemistry 36(4): 1243-1252. 